\title{
Aspects and Consequences of the Rwandan Law of Genocide Ideology: A Comparative Analysis ${ }^{1}$
}

\author{
Dominique E. Uwizeyimana (PhD) \\ Department of Public Management and Governance, University of Johannesburg \\ dominiqueu@uj.ac.za
}

Doi:10.5901/mjss.2014.v5n23p2370

\section{Abstract}

A number of countries have experienced genocide in the 20th century. The complexity in terms of the targets and the perpetrators of genocide has generated contradictory narratives and has complicated the interpretation and implementation of the laws of genocide in these countries and internationally. The objective of this paper is to analyse literature on the Rwandan genocide (1994), the Jewish Holocaust (1941-1945) and the Armenian genocide (1915-1917), in order to document circumstances surrounding the decision to implement (or not to implement) the laws of genocide ideology and the consequences for such decisions. One of the main findings of this research is that there are various scenarios for the application of the genocide ideologies, with narratives and their enforcement (or not) being quite different depending on the countries' circumstances.

Keywords: Rwandan genocide, genocide ideology, Jewish Holocaust, Armenian genocide

\section{Introduction}

The objective of this paper is to analyse literature on the implementation of the laws of genocide ideology and the consequences resulting from such implementation in countries such as Rwanda, Israel and Turkey. The paper starts by defining the concepts of genocide and genocide ideology and proceeds by providing documentation on the implementation of the laws of genocide ideology and the consequences in Rwanda. It then proceeds by documenting the circumstances surrounding the decision to implement (or not to implement) the genocide laws and the consequences of such decisions in other genocides cases, such as the Holocaust (1941-1945) and the Armenian genocide (1915-17). The paper concludes with evidence of similarities and differences in the circumstances surrounding each country's narratives of the genocide and enforcement (or not) of the laws of genocide.

\section{Attempts to Define the Term Genocide}

There are various definitions of the term genocide. According to Chalk \& Jonassohn (1990:1) "genocide is a form of onesided mass killing in which a state or other authority intends to destroy a group, as that group and membership in it are defined by the perpetrator". Harff \& Gurr (1988) further define the term genocide as "the promotion and execution of policies by a state or its agents which result in the deaths of a substantial portion of a group ... [when] the victimized groups are defined primarily in terms of their communal characteristics, such as ethnicity, religion or nationality". Most definitions emanate from the one which is provided in Article 2 of the International Convention of the Prevention and Punishment of the Crime of Genocide, adopted by the United Nations General Assembly on 9 December 1948. Article 2 of the UN's General Assembly Resolution 260A (III) defines the term genocide as "any act committed [by anyone] with intent to destroy, in whole or in part, a national, ethnical, racial or religious group". These acts may include:

(a) "Killing members of the group;

(b) Causing serious bodily or mental harm to members of the group;

(c) Deliberately inflicting on the group conditions of life calculated to bring about its physical destruction in whole or in part;

(d) Imposing measures intended to prevent births within the group;

(e) Forcibly transferring children of the group to another group" (United Nations, 1948:1).

\footnotetext{
${ }^{1}$ Special note: The views expressed in this article are solely the author's views and not the views of the Department of Public
} Management at the University of Johannesburg. 
The only difference is that while the majority of genocide scholars consider the "intent to destroy" and the participation of the state or its agents as sine qua non requirements for any act to be labelled genocide, the United Nations' definition does not specify who the main actor must be in order for any of the above acts to constitute genocide.

\section{The Rwandan Genocide}

According to the United Nations (1994:1) "the deaths of the Presidents of Burundi and Rwanda in a place crash caused by a rocket attack on the 6 April 1994, ignited several weeks of intense and systematic massacres in Rwanda. Between 500,000 and 800,000 Rwandans were murdered as part of a calculated effort by a group of Hutu extremists to eradicate the country's Tutsi population as well as the Hutus who did not support the genocide" (see also HRW, 2012:1). According to Rummel (2002:1) "genocide is foremost an international crime for which individuals, no matter how high in authority, may be indicted, tried, and punished by the International Criminal Court (ICC)". There are international laws such as the UN Convention for the Prevention and Punishment of the Crime of Genocide, adopted by the UN General Assembly on 9 December 1948 which came into force on 12 January 1951; which deal with such crimes against humanity in all countries that are signatories to it (Staton, 2012). The Rwandan government ratified and acceded to it (except Article 9 of the Convention) on 16 April, 1975 (Staton, 2012). Article 9 of this UN Convention states that "disputes between the contracting parties relating to the interpretation, application or fulfilment of the present Convention, including those relating to the responsibility of a State for genocide or any of the other acts enumerated in Article 3, shall be submitted to the International Court of Justice at the request of any of the parties to the dispute" (United Nations, 1948:1). The Rwandan government did not give reasons for its reservation at the time, but "most of the reservations have concerned the jurisdiction of the International Court of Justice set out in Article 9" (Schabas, 2008). The Rwandan reservation to Article 9 of the UN Convention was withdrawn on 15 December 2008, thereby declaring total ratification and commitment to all 19 Articles of the convention (Museminali, 2008). Article 9 of the Rwandan constitution claims that the Rwandan government "adheres to all the UN's Conventions, the Organisation of African Unity (OAU, currently known as African Union/AU) and many such international conventions" (Republic of Rwanda, 2010). Article 190 of the Constitution of the Republic of Rwanda further states that "the international treaties and agreements which have been conclusively adopted in accordance with the provisions of law shall be more binding than organic laws and ordinary laws..." (Republic of Rwanda, 2013:2). Thus, once ratified, all treaties and conventions supersede the national laws of any country that has ratified them (Chrisjohn, Wasacase, Nussey, Smith, Legault, Loiselle \& Bourgeois, 2002). However, while the Rwandan government has domesticated these international treaties and conventions, it enacted its own laws such as the Rwandan law of genocide ideology which laws are widely criticised for contradicting the very international treaties and conventions which Rwanda has ratified.

\section{The Rwandan Laws of Genocide Ideology (2008-2014)}

The origin of the term genocide ideology in not known. However, the infraction "genocide ideology" (also called "ingengabitekerezo ya jenoside" in the Rwandan language) is a term coined by the RPF-led Rwandan government following the 1994 Rwandan genocide. This term is defined in Articles 2 and 3 of Law No 18/2008 of 23/07/2008 relating to the punishment of the crime of genocide ideology as:

"an aggregate of thoughts characterized by conduct, speeches, documents and other acts aiming at exterminating or inciting others to exterminate people based on ethnic group, origin, nationality, region, colour, physical appearance, sex, language, religion or political opinion, committed in normal periods or during war" (Republic of Rwanda, 2014).

Article 3 of the same law goes on to describe the crime of genocide ideology as "any act or thought characterized by any behaviour manifested by facts aimed at dehumanizing a person or a group of persons with the same characteristics in the manner which include:

"threatening, intimidating, degrading through defamatory speeches, documents or actions which aim at propounding wickedness or inciting hatred; marginalising, laughing at one's misfortune, defaming, mocking, boasting, despising, degrading creating confusion aiming at negating the genocide which occurred, stirring up ill feelings, taking revenge, altering testimony or evidence for the genocide which occurred; killing, planning to kill or attempting to kill someone for purposes of furthering genocide ideology" (Republic of Rwanda, 2014: Article 3). 


\subsection{Criticisms of the 2008 Rwandan laws of genocide ideology}

Among the major criticisms of the 2008 law of genocide ideology and "sectarianism was that it was replete with ambiguity and confusion" (Amnesty International, 2010:1). It was said that these laws were so confusing that almost all Rwandans, the judges who are responsible for their interpretation and even parliamentarians who made them had no clear understanding of what exactly constitutes genocide ideology nor what conduct is criminal under these laws (Amnesty International, 2010). In 2006, that is, two years before the Rwandan laws of genocide were passed, the Rwandan Senate report was said to have admitted that it was not easy to provide a "systematic definition" of "genocide ideology" included in the law it had just passed (Rwandan Senate, 2006:16). "The confusion in this law was further complicated by its focus on perceptions of a speaker's alleged underlying philosophy, rather than whether the speaker's words constitute advocacy of hatred that amounts to violence, discrimination or hostility" (Amnesty International, 2010:2). Another major problem was its violation of international norms of justice such as innocent until proven guilty by the court of law and its violation of the principles of individual guilty (Human Right Watch, 2007: 1). Some of this law's violations of the principle of individual guilt were based on its prescription that "parents and teachers of children found guilty of teasing must face sentences of 15 to 25 years for the child's conduct" (Amnesty International, 2010:24). Critics of the Rwandan law of genocide ideology argue that "the principles of "innocent until proven guilty" and the "individual's responsibility" are fundamental principles to the legitimacy of the international judicial system which Rwanda has ratified" (Human Rights Watch, 2010:2-3). They also argue that "such broad laws are particularly dangerous because they are open to political influence in the sense that the State prescribes who to prosecute, on what charges and with what evidence" (Human Rights Watch, 2010:2-3). Such ambiguity and confusion in the Rwandan in the 2008 law of genocide have had major consequences in the administration of justice on both the accusers (i.e. presumed victims) and the accused (i.e. alleged perpetrators). According to Odette Yankurije, the Rwandan principal State Attorney "there were many incidences in which prosecutors would get confused and judges would declare the accusation irrelevant" or would prosecute and punish someone for things "which have nothing to do with the genocide or genocide ideology" (see also Human Rights Watch, 2010:3). For example, according to Amnesty International "One academic researcher in 2005 - before the "genocide ideology" law was promulgated - found that local officials in two communities "almost arbitrarily branded common petty crimes as genocide ideology whenever the alleged victims were Tutsi survivors and the alleged perpetrators were Hutu" (Human Rights Watch, 2010). In one such case, "a fight between two males (one a Hutu and another Tutsi) appeared to have been caused by an argument over a woman" (Human Rights Watch, 2010:3). There has also been evidence of people alleging genocide ideology while the real issue is jealousy (ibid). "There was also evidence of local politicians fabricating accusations of genocide ideologies in order to acquire land which belongs to those they are accusing" (Human Rights Watch, 2010:4). However, perhaps the most controversial aspect of the 2008 Rwandan law on genocide was that it was used to shield the people of the Tutsi ethnic background from war crimes, the crimes related to the genocide and genocide ideology committed before, during, and after 1994. For example, Article 13 of the Rwandan genocide ideology which was supposed to set penalties against false accusers - simply states that "Any person found guilty of false accusations of the crime of genocide ideology referred to in Article 4 of this Law shall be liable to the punishment provided for by the penal Code" (Republic of Rwanda, 2008:3). However, based on evidence provided here, if the person making an accusation is from the Hutu ethnic background then he/she is guilty of genocide ideology and must face the punishment which is described in different Articles of Chapter 2 of this law as summarised above. According to Ntaganzwa (2008:1), "following the Rwandan Patriotic Front overthrow of General Habyarimana's regime in 1994; the mention of Muhutu/Mututsi on Identity Cards was quickly abolished and replaced by the word Munyarwanda in order to build a sense of national unity". "In a country where it has become a taboo to identify someone or oneself as either Tutsi or Hutu" (Kok, 2008:1); such ethnic segregation contradicts the Rwandan government's claim that it has eliminated reference to the ethnicity. It is on the basis of these criticisms that Kabonero (2010) and Onyiego (2010) argued that "the Rwandan government is using the laws of genocide ideologies to silence critics and political opponents to President Paul Kagame rather than to provide justice". Such critics also include people like Grant (2010:1) who argues that, "just before the 9 August 2010 elections, only the Hutu opposition candidates were targeted for arrest and jailed and charged with "divisionism" and "genocide ideology". According to Grant (2010:1) "among the political opponents who were victims of the Rwandan laws of genocide ideology was former president Pasteur Bizimungu, the president of the Party for Democracy and Renewal-Ubuyanja (PDR-Ubuyanja), who was arrested in 2002 and sentenced to 15 years' imprisonment for divisionism". "The crime was allegedly committed in the course of a magazine interview in which Bizimungu predicted Hutu violence and civil war unless the RPF started sharing power in a concrete and genuinely democratic way" (Uwizeyimana, 2012:153, citing Grant, 2010:2-3). They also include former Prime Minister, Faustin Twagiramungu, who was the main opposition candidate in the 2003 presidential election (ibid). In 2003 "Twagiramungu 
"opted to run as an independent candidate after the government banned his party, the Movement Democratic Republican (MDR), and had many of its members imprisoned" under the laws of genocide ideology" (Patten, 2004:1; Rwandan Dream Youth's Declaration, 2013: 1). They also include Victoire Ingabire the president of the Unified Democratic Forces party - FDU Inkingi. Ingabire, who returned to Rwanda from the Netherlands with the intention of running in the 2010 presidential elections (Uwizeyimana, 2012:153; Uwizeyimana, 2014:6, citing Patten, 2004:1 and Grant, 2010: 2-3). When she arrived in Kigali, she allegedly called for the prosecution of those responsible for crimes against Hutus before, during, and after the 1994 Rwandan genocide (Uwizeyimana, 2014:6). She was immediately arrested, jailed and charged under the Rwandan law of genocide ideology for allegedly "dividing the people of Rwanda and denying the 1994 genocide" (Uwizeyimana, 2014:6, citing Van Leeuwen \& Houttuin, 2012:1). Ingabire was finally given an eight year jail term in October 2012 (Van Leeuwen \& Houttuin, 2012). Other victims of this Rwandan law of genocide ideology include foreign nationals such as Peter Erlinder, an American citizen and a lifetime-tenured professor of law at William Mitchell College of Law (WMCL) in the USA (Uwizeyimana, 2014). "Prof Erlinder was accused and jailed under the Rwandan genocide laws in 2010 for allegedly promoting the double genocide" (Herman \& Peterson, 2010:1-3). Critics such as Nickit (2014:1) argue that "Professor Erlinder's only crime was that he acted as defence counsel on behalf of the Hutus accused of genocide at the International Criminal Tribunal for Rwanda from 2003 to 2011". It is said that Erlinder's crime was that he challenged "by use of evidence in the hands of the United Nations, the United States Department of State, and the Rwandan Government, the dominant narrative of the 1990 - 1994 Rwandan war and attendant genocides" (Nickit, 2014:1). They also include academics such as Alan Stam, a professor of international politics at the University of Michigan and his co-author and researcher, Professor Christian Davenport, who, "after many years of study, and interviews with survivors [Stam and Davenport] found evidence to conclude that a million people died, the vast majority of those who died were not Tutsi, but Hutu... and current Rwandan President Paul Kagame, a U.S. ally trained at Fort Leavenworth, Kansas, is guilty of war crimes of an extraordinary scale" (Stam \& Davenport, 2009:8-9, see also Garrison, 2010). The two academics have been declared persona non grata for life in Rwanda, and their passports have been revoked simply because their research findings demonstrated that "genocide was only one among several forms of violence that occurred in Rwanda and that, contrary to the USA's and Rwandan government propaganda, atrocities in Rwanda were committed by both warring sides at the time" (Stam \& Davenport, 2009:8-9).

Thus, "while prohibiting hate speech is a legitimate aim for any country which has had large scale ethnic tensions such as Rwanda" (Amnesty International Report, 2010:1); "the use of Rwandan laws of genocide ideology to target a certain category of its population and to silence both national and international government critics violates both national and international laws and conventions" (United Nations Declaration of Human Rights, 1948:1; Amnesty International, 2010:34). Such laws include Rwanda's own constitution ("articles 6, 33, 34, as well as Articles 18, 19 of the Universal Declaration of Human Rights") which states that "Everyone has the right to freedom of thought, conscience and religion... (RDR, 2002:2)" "It is also in direct violation of the International Covenant on Civil and Political Rights (Article 19) as well as the 1789 Declaration of the Rights of Man and of the Citizen (Articles 6, 8, 11) on free communication of ideas, opinions; and freedom of speech" (Dalporto, 2012:893). Dalporto also argues that the "Rwanda's genocide ideology laws violate Article 20 of the African Charter of Human and Peoples' Rights" (Dalporto, 2012:893). The pressure resulting from these criticisms led to the Rwandan government undertaking to review its 2008 law of genocide ideology. However, as it will be demonstrated later, a closer analysis of these amendments shows clearly that the core problems were not dealt with.

\subsection{Amendment to the 2008 law of genocide ideology}

Following many years of intense pressure and lobbying the Rwandan government finally announced its plan to amend its 2008 law of genocide ideology in 2010. Among the major problems was that "the 2008 law could not differentiate genocide ideology and related offences such as minimizing, negating, and justifying the genocide" (Yankurije, as quoted in Tabaro, 2012:1). The Rwandan government claims that its amended law of genocide ideology punishes only "an intentional act in public, whether in a speech, writing, video or other medium and that the action must be characterised by thoughts based on ethnicity, religion, nationality or race to foment genocide and/or support genocide" (Kwesiga, 2013:1). The amendment sought to remove the vagueness and ambiguity from the law in the sense that the amended version outlines the differ $\neg$ ent acts that constitute genocide ideology (Gashugi, 2013:1). For example, according to Jean Pierre Kayitare, the Rwandan government's Assistant Attorney General, these acts include:

"incitement to commit genocide; negation of the genocide against the Tutsis, trivializing the genocide or jus?tifying it; and hiding or destroy-ing of evidence of genocide or of other crimes against humanity. Theft or destruction of remains of victims and violence against survivors are other offences it seeks to punish" (Kayitare, as quoted in Gashugi, 2013:1). 
Another new element is that "under the amended law, criminal intent must be proved, and an act of inciting genocide must be carried out in public (with the term public defined as in front of more than one person)" (SAPA-AFP, 2013:1). However, the said amendments in the new law do not say anything about 1.3 million people who have been prosecuted and condemned, some to death penalties or longer jail terms, under the old laws of genocide. There is no doubt that many of these people have been rightly found guilty for crimes they have indeed committed. However, the fact that the laws of genocide were ambiguous and were sometimes used to settle personal differences or to achieve political gains, as argued by some organisations such as Amnesty International Report (2010), logically suggest that some of them could also have been found guilty for crimes they did not commit or something which is not necessarily a crime. However, while the Rwandan government claims that the amended law makes that difference clear (Yankurije, as quoted in Tabaro, 2012:1) a closer analysis of the amended law shows clearly that the amendment did not deal with, let alone eliminate all possible confusions. For example, according to the Human Right Watch Report 2012 "vague offenses such as approving of the genocide by "mocking" a person or group on the basis of shared characteristics are still included in the said amended law" (Human Rights Watch, 2012:1-3).

In addition, while Yankurije and the Rwandan government acknowledge that "In the 2008 law, people were being held responsible for things that were said in private, which led to the many false accusations, the said amendments do not address the fact that only the people (children and adults) and organisations of people of the Ethnic Hutu background are still the sole target for this law of genocide ideology". Furthermore, since the prosecution is said to be based - not on the actual statement, but on the underlying philosophy as determined by the State or its agents, the amendments in the new law do not provide objective measures to interpret and determine beyond reasonable doubt that the alleged criminal's thoughts constitute the crime of genocide ideology. Furthermore, according to Karake (2012:1) and the Freedom House Report (2013:10) "the law still restricts freedom of expression by retaining the notion of "genocide ideology" as a criminal offense and by excluding a clear distinction between a private conversation and public speech". Thus, according to the Human Right Watch Report 2012, "while the revisions of the laws on genocide ideology and media contained some positive amendments, they left open the possibility for inappropriate prosecutions for genocide ideology" (Human Rights Watch, 2012).

Most importantly, the Rwandan law of genocide in general and its amended version in particular, are criticised by most Rwandans and non-Rwandan individuals and organisations for failing to recognise the fact that both Hutus and Tutsis were victims of genocidal violence that affected Rwandans before, during, and after the 1994 genocide (Human Rights Watch, 2012). The recognition of the loss of lives on the side of the Hutus continues to be criminalised by the Rwandan law of genocide ideology and is called "double genocide Theory" "or genocide denialism". This continues to be the case, despite the findings of a number of independent studies and testimonies by a number of former Rwandan Patriotic Front (RPF/RPA) members which leave no shadow of doubt that both warring sides of the Rwandan war (19901994 and beyond) committed atrocities against Rwandan citizens. These include Reyntjens, Des Forges and Stam, but also a number of former RPF rebels such as Kennedy Gihana and Ruzibiza (among others) who allege that indeed the double genocide took place in Rwanda before, during, and after the 1994 period. According to Reyntjens (1996:240) "the Rwandan Patriotic Front (RPF) killed tens of thousands, maybe hundreds of thousands of Rwandans before, during, and after 1994". Reyntjens views are supported by Stam and Davenport's study which found that while "a million [of Rwandan] people died, the vast majority of those who died were not Tutsi, but Hutu... and current Rwandan President Paul Kagame [and RPF/A members] ... are guilty of war crimes of an extraordinary scale (Stam \& Davenport, 2009)." Des Forges argues that "the killings by the RPF were more selective, mainly targeting educated or politically active Hutus" (Des Forges, 1999:692). The views of these authors are well supported by a number of RPF ex-combatants whose own hands did the killings. Among them are Kennedy Gihana (nicknamed Rambo), an ex-rebel soldier who was in the frontline of an attack on the capital Kigali in April 1994 (Pauw, 2013). Gihana alleges that he and all other RPF combatants had been given "the orders to kill every Hutu, irrespective of age and gender" because according to him "Nobody was taking prisoners" (Gihana, cited in Pauw, 2013:17). The testimony given by Major Alphonse Furuma, a former Rwandese Patriotic Army Political Commissar during the RPA war (1990-1994), and later Aide de Camp (ADC) to the former army Chief of Staff General Kayumba Nyamwasa (1998-2010) also alleges that "taking no prisoner of war" was a general policy of the RPF since its invasion on 1 October 1990 to the time it took power in Rwanda in 1994. According to Faruma "Kagame, the Commander-in-Chief of the Rwandan Patriotic Army (RPA) and Minister of Defence and Vice-President at the time (1994-2002) ordered counter genocide massacres covering the entire nation immediately the genocide started". According to Gihana, all RPA Units were under orders to kill any Hutu on sight and for several months, and, according to him, "many soldiers did kill as many Hutu as they could" (Gasana, 2010). Other people from the Rwandan Patriotic Front (RPF) who allege that the genocidal massacre which took place in Rwanda since 1 October 1990 killed both Hutus and Tutsis, include General Kayumba Nyamwasa, the former Chief of Staff of Rwanda's armed forces; the late Colonel 
Karegeya, former Chief of external security/spy services; Major Rudasingwa, Kagame's former Director of Cabinet and Rwanda's first post-genocide ambassador to the US as well as Gerald Gahima, Rwanda's former Prosecutor General and Vice President of the Supreme Court, to name but a few (Gasana, 2010:10). "All four former comrades-in-arms of President Paul Kagame now live in exile and many of them have international warrants of arrest for war crimes and crimes against humanity" - but not one of them was ever convicted for the same crimes in Rwanda (Fabricius \& Roane, 2014:1). Some of these former RPF soldiers, such as Nyamwasa, can be heard in the recently released documentary: The Rwanda's Untold Story" admitting the guilty and have publicly asked forgiveness for the crimes they have committed from the Rwandan people of the Hutu tribe (Corbin, 2014). It is this continued contradiction in the current Rwandan law of genocide ideology which led Cobban (2001:1) to argue that "domestic trials which have been politicized and of which many Rwandans view as one-sided... compromise their ability to promote the rule of law". Most Rwandans, irrespective of their ethnic background, agree that there cannot be peace and reconciliation in Rwanda until those RPF members who killed the Hutus are also brought to justice and the Hutus are allowed to remember their own relatives who perished at the hands of RPF soldiers inside and outside the country (see Corbin, 2014).

Thus, the only meaningful and new thing in the amended law is, that the punishments for genocide ideology and related offenses have been reduced. For example, while the 2008 law of genocide ideology prescribed punishments which could amount to 25 years or even life in prison plus fines between Frw 100,000 to 1,000,000, the punishments in the new law range from 5 to 9 years.

\section{The Armenian Genocide (1915-1917)}

According to Cohan (2005:333) "from 1915 to 1917 the Young Turk regime in the Ottoman Empire carried out a systematic, premeditated, centrally-planned genocide against the Armenian people". The Armenian Genocide refers to the "forced mass evacuation, execution, starvation, disease, the harsh environment, and physical abuse by the Turkish army of Armenians between 1915 and 1917" (Smith, Markusen \& Lifton, 1995:3). Some estimate that between "80,000 and 300,000 Ottoman Armenians were killed between 1915 and 1917 (Cohan, 2005:333) but others mention more than 1 500000 Armenian deaths" (Smith et al. 1995:3). A closer look at the available literature identifies two possible causes of the Armenian genocide. The first is religion. It is said that the Armenians were Christians and a minority, while the Turks were Muslims and a majority (Smith et al. 1995:2). Therefore, the Turkish government killed the Armenians because it considered them "religious infidels and political traitors" (Cohan, 2005:336). The other is political. This is because, "when WWI broke out in 1914, leaders of the Young Turk regime (ruling the Ottoman Empire) sided with the Central Powers (Germany and Austria-Hungary), while the Armenians are said to have sided with the Russians" (Cohan, 2005). The "Ottoman Empire was badly defeated by the Russians and their allies in the winter of 1914-15" (ibid). There is therefore a view that the Armenian community was made a "scapegoat for the Ottoman Empire's military losses at the hands of the Russians" (Cohan, 2005:336). However, contrary to the Rwandan scenario discussed above, the Turkish government has never recognised the Armenian genocide and has continued to make extraordinary efforts to stop other governments from recognising that it occurred.

\subsection{Turkish Efforts to deny the Armenian genocide of 1915-17}

A number of western countries such as "Russia, France, the Vatican State and the USA claim that the massacres carried out by the Turkish government at the time were a case of genocide" (New World Encyclopaedia, 2012:1). However, literature shows that the Turkish government continues to make extraordinary efforts to stop other governments from recognising that the 1915 genocide against the Armenians occurred. "The narrative of the Turkish government and some of its supporters is that the deaths of thousands Armenians were the result of inter-ethnic strife and turmoil during World War I and not of a state-sponsored plan of mass extermination" (New World Encyclopaedia, 2012:1). Some of the extraordinary efforts being made by the Turkish government to deny the Armenian genocide and to stop other governments from recognising it include "making laws that criminalize describing the event as genocide, to publicly rebuke any government which recognises the Armenian genocide and most importantly to discredit any academic who presents evidence of this genocide" (Smith et al. 1995:3). Perhaps one of the best articles that describes the Turkish government's efforts to deny the Armenian genocide of 1915-17 and its efforts to discredit any academic who presents evidence of this genocide was presented by Smith, Markusen \& Lifton, in their 1995 article entitled "Professional Ethics and the Denial of Armenian Genocide" (Smith et al. 1995:3). In this article, the authors argue that tactics of denial have shifted over the years, but they have always included "Trying to find scapegoats to blame for what they say was only a security measure that had gone awry due to unscrupulous officials, Kurds, and common criminals" (Smith et al. 1995:1). 
The Turkish government has also attempted to avoid the whole issue, "by silence, diplomatic efforts, and application of political and economic pressure where possible". For example, "in the 1930s, the Turkish government pressured the US State Department into preventing MGM Studios from producing a film based on Franz Werfel's The Forty Days of Musa Dagh, a book that depicted aspects of the Armenian genocide in a district located west of Antioch on the Mediterranean Sea, far from the Russian front" (Smith, et al. 1995:2). In the 1960s, "prompted by the worldwide commemoration of the fiftieth anniversary of the Armenian genocide, efforts were made to influence journalists, teachers, and public officials to tell the other side of the story" (Smith et al. 1995). This time, "foreign scholars were also encouraged to revise the record of genocide and to present an account largely blaming the Armenians or, in another version, wartime conditions which claimed the lives of more Turks than Armenians" (Smith et al. 1995:2). It is not clear whether the Turkish government was trying to claim "double genocide" a concept which the Rwandan government is fighting hard to avoid. Thereafter, "Turkey tried to prohibit any mention of the genocide in a United Nations report and was successful in its pressure on the Reagan and Bush administrations in defeating Congressional resolutions that would have designated "April 24" of each year as a national day of remembrance of the Armenian genocide in the United States" (Smith et al. 1995:3). The Turkish denial of the Armenian genocide has also attempted to exclude any mention of the genocide from American textbooks (Smith et al. 1995). "Stronger efforts were made to prevent any discussion of the 1915 genocide being formally included in the social studies curriculum as part of Holocaust and genocide studies" (Smith et al. 1995:4). In fact, the Turkish government has gone as far as attempting to disrupt academic conferences and public discussions of the genocide (Smith et al. 1995). A notable example given by Smith, et al. (1995), is that in which "Turkish officials threatened to disrupt a conference by force in Tel Aviv in 1982 if the Armenian genocide were to be discussed". The demand for the removal of the Armenian genocide was "backed up with threats to the safety of Jews in Turkey" (Smith, et al. 1995). "The US Holocaust Memorial Council reported similar threats over plans to include references to the Armenian genocide within the interpretive framework of the Holocaust Memorial Museum in Washington" (Smith et al. 1995:4).

The Turkish government efforts also include "funding research institutes and academic programmes designed to reject the Armenian genocide" (Smith et al. 1995:4). For example, Smith, et al. (1995) depict an arrangement by which the "Turkish government channelled funds into a supposedly objective research institute in the United States, which in turn paid the salary of a historian who served that government, in its campaign to discredit scholarship on the Armenian genocide". In addition in the "1980s the Turkish government supported the establishment of "institutes" whose apparent purpose was to encourage research on Turkish history and culture" (Smith et al. 1995:4). However, according to these authors, "at least one institute was used to encourage denial of Turkish genocide and otherwise improve Turkey's image in the West" (Smith, et al. 1995). The Turkish government has been successful in stopping powerful countries from making the denial of the Armenian genocide a crime. For example, "in 2006, the French National Assembly passed a bill that would penalise what it called negationism of the Armenian Genocide" (Viscusi \& Peker, 2011:12). The law would punish denial of any genocide recognized by French law with as long as "a year in prison and a 45,000 Euro $(\$ 59,000)$ fine (2006 exchange rate)" (Viscusi \& Peker, 2011:12). However, because of the political and economic pressure from the Turkish government this law was ruled unconstitutional by the country's top judicial body before it was signed into Law by President Sarkozy (Viscusi \& Peker, 2011). After the French lower house approved the bill in 2006, "Erdogan blocked Gaz de France SA's participation in the 7.9 billion Euro Nabucco pipeline and suspended military relations with the French government" (Irish \& Villelabeitia, 2011:1). In 2010, "Turkey withdrew its ambassador from the US after a House of Representatives committee approved a resolution recognizing the killings as genocide" (Irish \& Villelabeitia, 2011).

\section{The Jewish Holocaust (1941-1945)}

The word "Holocaust," from the Greek words "holos" (whole) and "kauston" (burned), (i.e. literally, "a completely burned sacrifice, whole burnt-offering or destruction"(Fowler \& Fowler, 1965:58) was "historically used to describe a sacrificial offering burned on an altar" (Wistrich, 1991). "Since 1945, the word has been used to describe the mass murder of some 6 million European Jews (as well as members of some other persecuted groups, such as Gypsies and homosexuals) by the German Nazi regime during the Second World War (1933-1945)" (Wistrich, 1991:2). It is believed that the Holocaust was a result of a doctrine known as "Anti-Semitism" which literally means "hostility towards the Jews" (Wistrich, 1991:2). "To the anti-Semitic Nazi leader Adolf Hitler, Jews (and other non-Aryans) were an inferior race, an alien threat to German (i.e. Aryans) racial purity" (Elliott, 1970:242). "After years of Nazi rule in Germany, during which Jews were consistently persecuted, Hitler's "final solution"- now known as the Holocaust; came to fruition under the cover of world war, with mass killing centres constructed in the concentration camps of occupied Poland between 1933 and 1945" (Burleigh, 1991:1-2). 


\subsection{The laws of genocide ideology and the prosecution and reparation of the victims of the holocaust}

This paper has shown that the 1948 UN Convention for the Prevention and Punishment of the Crime of Genocide came into force on 12 January 1951. Thus, "when the Nuremberg trials started in November 1945" (Overy, 2011:1), this UN Convention was not in force for the trials of the Nazis who committed genocide against the Jewish people (1933-1945). It is for this reason that "the Allied Control Council issued Control Law No. 10, established the basis for "the prosecution of war criminals and similar offenders was enacted by Allied Forces on 20 December 1945" (Linder, 2000:2). "Each of the occupying authorities was authorized, in its occupation zone, to try persons suspected of committing war crimes under this law" (Linder, 2000:2). "Many of the Nazi members and supporters were convicted and sentenced to death penalties, life imprisonment and different jail terms (ibid). Germany was also forced by the Allied Forces (USA, UK, France etc.) to admit the guilt of the Holocaust and to pay heavy reparations for the Jewish Holocaust of 1933-1945 (AFP, 2010). German reparations of about " $£ 14$ million each year were completed in 1965" (Elliott, 1970:242). Therefore, unlike Turkey which denies the Armenian genocide and the Rwandan government (which denies the double genocide), Germany has never denied the responsibility of its people (i.e. the Nazis) in the Jewish Holocaust. In fact, Germany currently leads the efforts to criminalise Holocaust denial and the banning of the public display of Nazi insignia in all EU member states. "Recalling the way in which the anti-Semitic words of Hitler and other Nazi sympathisers paved the way for the horrors of Nazism", Brigitte Zypries, the current German minister of justice, states that "This historical experience put Germany under a permanent obligation to combat systematically every form of racism, anti-Semitism and xenophobia (Zypries cited in Ash, 2007:1). Currently, there are about "237 countries and territories (such as Iran and Turkey etc.) where Holocaust denial is legally allowed (i.e. not a crime)"; but, a number of countries such as "Germany, Austria, Belgium, the Czech Republic, France, Germany etc. criminalise the denial of the Holocaust" (Weiller \& Pech, 2009:1). However, despite these convictions (and perhaps because the German government had taken full responsibility and was paying reparation to the newly founded Jewish state of Israel), there is no other known comprehensive lawsuit unifying the demands of the survivors of the Jewish Holocaust for reparation from the German government. The known recent case is the "Class action lawsuit", which is led by the Yesh organization for Children and Orphan Holocaust Survivors in Israel which demands compensation from the German government but, according to Regev (2009) the State of Israel was not a part of this lawsuit.

\section{Conclusion and Recommendations}

The objective of this paper was to analyse literature in order to document circumstances surrounding the decision to implement (or not to implement) the genocide ideologies and the consequences such decisions have had on the "target" and "perpetrators" of genocide. Among the selected countries was the Rwandan genocide (1994), the Jewish Holocaust (1941-1945) and the Armenian genocide (1915-17). The article has found that such diversity of circumstances surrounding the genocides has led to different narratives in which the events described as genocide are emphasised by some (especially those who see themselves as the victims) while rejected by others (especially those who are alleged to be the perpetrators. However, Rwanda and Turkey are also different in some important ways. For example, while Rwanda goes to great lengths to deny the "double genocide" and use the "law of genocide ideology" to silence anyone who would like to raise such a sensitive issue, Turkey seems to somehow encourage it in its claim that more Turkish people died than Armenians (1915 - 1917). The Rwanda government tactically and systematically encourages the mentioning of the Rwandan genocide as the "Genocide against the Tutsis only (jenoside y'abatutsi)", in order to minimise claims that RPF members also killed Hutus; while the Turkish government seems to promote the view that Turks died and that the Armenian genocide was a simple administrative error. The differences in handling the issue of genocide that took place in these two countries is based on the fact that the RPF government currently running Rwanda is generally made up of an ethnic group which was the target of the 1994 genocide, which they squarely blame on the Hutu, while the Turkish government is accused of being the perpetrator of genocide against the Armenians. Therefore, while the government in Rwanda stands to benefit from the "status of being survivors/victims of the genocide", the Turkish governing elites stand to lose if they accept the guilt of having committed genocide. Most importantly, the Turkish government fears that an admission of guilt would impose the necessity of paying reparation to the Armenian victims of genocide (as Germany did to the Jews).

Finally, the Jewish Holocaust is different from the Rwandan and the Armenian genocides in so many important ways. For example, while a number of countries such as Iran and Turkey still deny the Jewish holocaust, the Jewish holocaust is unique in the sense that it has gained international acceptance especially in the European Union and the USA. The Jewish Holocaust was also different from any other known genocide because, unlike the Rwandan and 
Armenian genocides, the Jews were clearly and totally defenceless. That is, the Jews are the only victims of genocide who did not have a military organisation fighting for them against the group or country which committed the genocide. For example, unlike the Jewish Holocaust, the Tutsis in Rwanda had RPF and the Armenians had an army. The RPF army went on to take power while the Armenian army was disarmed before the start of the genocide. Therefore, other than ghetto rebellions undertaken in desperation, the murder of the Jews by the Nazis was not due to any opposition the Jews offered to the ruling Nazis or the German state. The Jews had no ambitions to overthrow the Nazi government as was the case with RPF members in Rwanda. There is also no known evidence to suggest that the Jewish community/state attempted to take revenge on the Germans, which would constitute a double genocide as is the case in Rwanda. Furthermore, unlike the Jewish genocide which included Jews who lived in countries such as Poland, USSR, and France etc.; members of the Rwandan government who committed the genocide in 1994 targeted the Tutsis who were living inside Rwanda at the time. The 1994 Rwandan genocide did not directly touch the Tutsis who lived in neighbouring Uganda, Tanzania, DRC, Burundi and other countries. Finally, unlike the Rwandan and the Armenian genocides which the perpetrators have always denied; Germany has not officially denied that a section of its people in the name of Nazis carried out the Jewish Holocaust. In fact, instead of denying the Jewish Holocaust or attempting to stop other countries from recognising it, Germany is leading the campaign to criminalise the denial of the Holocaust in other countries.

Based on the above analysis, a universal and just application of international laws of genocide and crimes against humanity is strongly recommended in order to punish all perpetrators of genocide and to avoid the real or perceived "victor's justice".

\section{References}

AFP (2010). Germany finally pays off WWI debt. http://news.smh.com.au/breaking-news-world/germany-finally-pays-off-wwi-debt-20100930-15ydu.html [Accessed: 06 March 2013].

Amnesty International (2010). Safer to Stay Silent The chilling effect of Rwanda's Laws on 'genocide ideology' and 'sectarianism. http://www.concernedhistorians.org/content_files/file/TO/236.pdf [Accessed: 24 October 2012].

Ash, T.G. (2007). A blanket ban on Holocaust denial would be a serious mistake. The Guardian, Thursday 18 January. http://www.guardian.co.uk/commentisfree/2007/jan/18/comment.secondworldwar [Accessed: 26 March 2013].

Burleigh, M. (1991).The Racial State: Germany 1933-1945. New York: Cambridge University Press.

Chalk, F \& Jonassohn, K. (1990). The History and Sociology of Genocide: Analyses and Case Studies, Yale University Press: Yale.

Chrisjohn, R. D. Wasacase ,T. Nussey , L. Smith, A. Legault, M. Loiselle, P. \& Bourgeois, M. (2002). Genocide and Indian residential schooling: the past is present. http://www.nativestudies.org/native_pdf/pastispresent.pdf (Accessed: 07 March 2013].

Cobban, H. (2001). The Legacies of Collective Violence: The Rwandan genocide and the Limits of Law. Boston Review 7 (2).

Cohan, S. (2005). A Brief History of the Armenian Genocide. Social Education, 69(6):333-337.

Corbin, J. (2014). Rwanda's Untold Story. BBC.\#This world. http://vimeo.com/107867605 (accessed: 28 October 2014).

Davenport, C. \& Stam, A.C. (2009). What Really Happened in Rwanda? http://www.psmag.com/politics/what-really-happened-in-rwanda-3432/ [Accessed: 24 October 2012].

Dalporto, C. (2012). Genocide ideology laws: violation of Rwandan peoples' 'peoples' rights'?

CARDOZO J. OF INT'L \& COMP. LAW (2012): 20. p875. http://www.cjicl.com/uploads/2/9/5/9/2959791/cjicl_20.3_dalporto_note.pdf, [Accessed: 07 March 2013].

Des Forges, A. (1999). Leave none to tell the story. New York: Human Rights Watch.

Des Forges, A. \& Longman, T. (2004). Legal Responses to Genocide in Rwanda. In My

Neighbor, My Enemy: Justice and Community in the Aftermath of Mass Atrocity", ed. Eric Stover and Harvey Weinstein. Cambridge: Cambridge University Press.

Elliott, F. (1970). Dictionary of Politics. Penguin Reference Books: London.

Fabricius, P. \& Roane, B. (2014). 'I drove killer to Michelangelo'. http://www.iol.co.za/news/africa/i-drove-killer-to-michelangelo-1.1628122\#.U7_AaLcaLIU [accessed: 11 July 2014].

Fowler, H.W. \& Fowler, F.G. (1965). The Concise Oxford Dictionary of Current English, London: Oxford University Press.

Freedom House (2013). Freedom On The Net 2013: Rwanda. http://www.freedomhouse.org/sites/default/files/resources /FOTN\%202013_Rwanda.pdf (accessed: 28 October 2014).

Gasana, DM., (2010). RPF Founders attack Kagame. The Newsline. http://www.musabyimana.be/fileadmin/user_upload/documents/ 2009/Newsline_n_006_9-16_sept_2010.pdf, [Accessed: 08 March 2013].

Garrison, A. (2010). Rwanda's packed prisons and genocide ideology law, San Francisco Bay View, p1.

Gashugi, O.A. (2013). "Clearer Genocide ideology law to be more lenient". http://focus.rw/wp/2013/08/clearer-genocide-ideology-law-to-be-more-lenient/ [accessed: 08 April 2014].

Grant, R. (2010). Paul Kagame: Rwanda's redeemer or ruthless dictator? http://www.telegraph.co.uk/news/worldnews/ africaandindianocean/rwanda/7900680/Paul-Kagame-Rwandas-redeemer-or-ruthless-dictator.html [accessed: 11 July 2014].

Harff , B \& Gurr, T. (1988). Toward empirical theory of genocides and politicides, International Studies quarterly, 37(3):1

Herman E.S. \& Peterson, D. (2010). "Peter Erlinder Jailed by One of the Major Genocidaires of Our Era". http://mrzine.monthlyreview.org/2010/hp290510.html [accessed: 11 July 2014].

HRW (2007). The 37-pages report, entitled "There Will Be no trial: Police Killings of Detainees and the Imposition of Collective Punishment. Http://hrw.org/english/docs/2007/07/23/rwanda16455.htm [Accessed: 22 November 2012];

HRW Report, (2009). You Will Be Punished. http://www.hrw.org/en/node/87142/section/5 [Accessed:24 October 2012]. 
HRW, (2012). World Report 2012: Rwanda. http://www.hrw.org/world-report-2012/world-report-2012-rwanda, [Accessed: 12 April 2013].

Irish, J. \& Villelabeitia, I. (2011). France passes genocide bill, angry Turkey cuts ties. http://www.reuters.com/article/2011/12/22/us-france-turkey-genocideidUSTRE7BL1FB20111222, [Accessed: 27 February 2013].

Jones, A. (2006). Genocide: A Comprehensive Introduction, Routledge/Taylor \& Francis Publishers.

Kabonero, C. (2010). Rwanda: undefined 'divisionism' used to criminalize dissent. http://www.musabyimana.be/fileadmin/user_ upload/documents/2009/Newsline_n_006_9-16_sept_2010.pdf, [Accessed: 08 March 2013].

Karake, ER (2012). "Gov't Seeks to Amend Genocide Ideology Law," New Times, November 3, 2012, http://www.newtimes.co.rw/news/index.php?i=15165\&a=60288 (accessed: 28 October 2014).

Kok, N. (2008). Rwanda 'The Closing of the Gacaca Courts and the Implications for Access to Justice', www.cdea.or.tz/../rwanda-the-closing-of-the-gacacacourts-and-the-impl [accessed 09 May 2013].

Kwesiga, B. (2013). Rwandan Senate approves genocide law, Africa Review, August 1, 2013. http://webcache.googleusercontent. com/search?q=cache:RCLkodKv49MJ:www.redpepper.co.ug/rwandan-approves-genocide-law/+\&cd=1\&hl=en\&ct=clnk\&gl=za [accessed: 08 April 2014].

Linder, D. (2000). The Subsequent Nuremberg Trials: An Overview. http://law2.umkc.edu/faculty/projects/ftrials/nuremberg/ subsequenttrials.html, [Accessed: 26 March 2013].

Museminali, R., (2008). Convention on the Prevention and Punishment of the crime of

Genocide, 9 December 1948:Withdrawal of Reservation on 15 December 2008. http://www.icrc.org/ihl.nsf/NORM/3F1FB6 E802770E00C125642F0043 A712?OpenDocument, [Accessed: 07 March 2013].

New World Encyclopaedia, (2012). Armenian Genocide. www.newworldencyclopedia.org/entry/Armenian_Genocide [Accessed: 27 February 2013].

Nickit, P. J. (2014). Professor Peter Erlinder vs. William Mitchell College of Law, Case File 62-cv-14----/breach of contract, tort, and other.http://www.ihli.org/wp-content/uploads/2014/02/2014-01-17-Erlinder-v-WMCL-et-al-First-Amended-Complaint.pdf [accessed: 30 April 2014].

Ntaganzwa, I (2008). 'Teaching History after Identity-Based Conflicts: The Rwandan Experience'(2008), Comparative Education Review 2008.

Onyiego, M. (2010). Legacy of Genocide Fuels Political Repression in Rwanda. http://www.voanews.com/content/legacy-of-genocide-fuels-politicalrepression-in-rwanda-101895988/124908.html, [Accessed: 08 March 2013].

Overy, R. (2011). Nuremberg: Nazis On Trial.http://www.bbc.co.uk/history/worldwars/wwtwo/nuremberg_article_01.shtml [Accessed: 26 March 2013].

Patten, C. (2004). Report for the European Union parliament's commission on the 2003 election in Rwanda. http://europa.eu.int/ comm/externalrelations/humanrights/eu_election_ass_observe/rwanda/ip03_1142.htm, [Accessed: 1 December 2011].

Pauw, J. (2013). The long road from Rwanda" interview with Kennedy Gihanain April 2011. Johannesburg, City Press, p17.

RDR (2002) RDR condemns non-free and unfair local elections in Rwanda. Press Release Number 4. http://www.grandslacs.net/doc/2203.pdf (accessed 14 November 2013).

Regev, D. (2009). Holocaust children to sue Germany. http://www.ynetnews.com/articles/0,7340,L-3446102,00.html. [Accessed: 06 March 2013].

Republic of Rwanda, (2008). Article 2 of Law No18/2008 of 23/07/2008, p1; The Independent Team, 2010. Genocide ideology faces fresh scrutiny. http://www.independent.co.ug/reports/special-report/3463-genocide-ideology-faces-fresh-scrutiny, [Accessed: 16 October 2012].

Republic of Rwanda, (2010). The Constitution of the Republic of Rwanda of 4th June 2003 as Amended on 17 June 2010.

Republic of Rwanda (2013). Title X: International treaties and agreements, Article 190 of the Constitution of the Republic of Rwanda. http://www.rwandahope.com/constitution.pdf (accessed: 21 August 2013).

Reyntjens, F. (1996). Rwanda: Genocide and beyond. Journal of Refugee Studies 9 (3):240-51.

Roger, S. Markusen, W. E. \& Lifton, R. J. (1995). Professional Ethics and the Denial of Armenian Genocide. Hdocaust and Genocide Studies 9 (l):1-22.

Rummel, R.J. (2002). Genocide. http://www.hawaii.edu/powerkills/GENOCIDE.ENCY.HTM, [Accessed: 12 April 2013].

Ruzibiza, A. J. (2005). Rwanda : L'histoire secrete. Paris: Editions du Panama.

Rwandan Senate, (2006). Rwanda: Genocide Ideology and Strategies for its Eradication. http://books.google.co.za/books/ about/Rwanda.html?id=GsSFMwEACAAJ\&redir_esc=y [accessed: 11 July 2014].

Sapa-AFP (2013). "Rwanda parliament votes to amend genocide law. http://www.timeslive.co.za/africa/2013/07/17//rwanda-parliament-votes-to-amendgenocide-law [accessed: 08 April 2014].

Schabas, W. A. (2008). Convention for the prevention and punishment of the crime of genocide United Nations Audiovisual Library of International Law. http://untreaty.un.org/cod/avl/pdf/ha/cppcg/cppcg_e.pdf, [Accessed: 07 March 2013].

Shaba, E.B. (2011). Suede: Umuyobozi w'Ishyaka Democratic Green Party. Umusoto 29 April 2011, p1-3. http://groups.yahoo.com Igroup/Umusoto/message/30347, [Accessed: 14 November 2011].

Staton, G. H. (2012). Scholars raise awareness on genocide prevention. http://www.newtimes.co.rw/news/views/article_print. php?i=15211\&a=61956\&icon=Print, [Accessed: 07 March 2013].

The US and the Holocaust (2010). Israel: What did the United States know? And when did they know it?" http://www.hellonewman.com/lsrael/holocaust.html, [Accessed: 28 February 2013].

United Nations, (1948). The International Convention of the Prevention and Punishment of the Crime of Genocide, 9 December 9, 1948.

Uwizeyimana, D. E., (2012). Democracy and pretend democracies in Africa: Myths of African democracies. Law, Democracy \& Development, Vol (16):153.

Uwizeyimana, D. E. (2014). International donors' obliviousness to human rights violations and lack of democracy in their disbursement of aid: a case of postgenocide Rwanda1. Journal of Asian and African Studies, 0021909614547601.

van Leeuwen, S. \& Houttuin, S. (2012). Eight years for Victoire Ingabire. http://www.rnw.nl/africa/article/eight-years-victoire-ingabire, [Accessed: 20 March 2013].

Viscusi, G. \& Peker, E. (2011). French Assembly Approves Armenian Genocide Law as Turkey Lobbies. http://www.businessweek.com/ news/2011-1223/french-assembly-approves-armenian-genocide-law-as-turkey-lobbies.html, [Accessed: 27 February 2013].

Weiller, J. H. H. \& Pech, L. (2009). The Law of Holocaust Denial in Europe: Towards a (qualified) EU-wide Criminal Prohibition. www.JeanMonnetProgram.org [Accessed: 01 March 2013].

Wistrich, R.S. (1991). Anti-Semitism: The longest hatred. New York: Pantheon Brooks. 